\title{
Legal Abortion Levels and Trends By Woman's Age at Termination
}

CONTEXT: Assessments of abortion levels and trends by women's age at termination can be used to monitor trends in unintended pregnancy by age and can inform relevant programs and policies.

METHODS: Legal abortion incidence data were compiled from national statistical offices and nationally representative surveys of more than 40 countries where legal abortion is generally available. Age-specific abortion rates and percentage distributions of abortions by age were computed, and trends since 1996 and 2003 were examined. Subregional and regional estimates were developed for geographic areas where the majority of the population was represented by the data.

RESULTS: The median year for the most recent estimates of abortions by woman's age was 2009. Adolescents accounted for a smaller share of abortions than their share of the population in the majority of eligible countries with data. In most countries, the highest age-specific abortion rates and proportions of abortions were among women aged 20-29. Since 1996, adolescent abortion rates have increased the most in Belgium, the Netherlands and Scotland (22-42\%), and have decreased the most in Estonia, Hungary, Iceland, Slovakia and Slovenia (40-55\%). The proportion of abortions obtained by adolescents was higher in North America (18\%) than in Europe overall (11\%), although the proportion in Northern Europe (18\%) was the same as that in North America.

CONCLUSIONS: Higher abortion rates in particular age-groups probably reflect higher-than-average levels of unmet need for contraception or difficulty using methods consistently and effectively, and a stronger desire to avoid childbearing. Each of the patterns observed has implications for service and information needs within countries. International Perspectives on Sexual and Reproductive Health, 2012, 38(3):143-153, doi: 10.1363/3814312
By Gilda Sedgh, Akinrinola Bankole, Susheela Singh and Michelle Eilers

Gilda Sedgh is senior research associate, Akinrinola Bankole is director of international research, Susheela Singh is vice president for research and Michelle Eilers is research assistant-all with the Guttmacher Institute, New York.
Worldwide, the incidence of induced abortion has remained steady in recent years after declining in the 1990s and early 2000s. ${ }^{1}$ The same is not true, however, for each individual country for which information on abortion trends is available: In many, the incidence of abortion has continued to decline, and in a few, it has risen. ${ }^{2}$

Abortion levels and trends can also vary within countries, across subgroups of women. ${ }^{3}$ Documentation of abortion incidence is unavailable in most countries with highly restrictive abortion laws, and quantitative information on the characteristics of women who have abortions in such countries-including their age, marital status and parity-is even more scarce. However, abortion data collection systems are in place in most countries with liberal abortion laws. The information obtained about women having abortions differs across these countries; age is perhaps the most commonly recorded characteristic.

Groups of women with disproportionately high abortion rates likely have an exceptionally difficult time avoiding unintended pregnancies or a greater motivation to terminate such pregnancies. In many societies, young unmarried women who are sexually active might have a particularly difficult time avoiding unintended pregnancies, because fear of the stigma attached to nonmarital sexual activity can inhibit them from obtaining contraceptive services and from using methods correctly and consistently. In addition, young women may find it difficult to negotiate contraceptive use with their partners. Unplanned births among adolescents and young adults can carry high opportunity costs-sometimes forcing them to curtail their schooling and, thus, adversely affecting their future employment prospects and sometimes compromising their ability to establish stable partnerships. ${ }^{4,5}$ On the other hand, sexual activity is less prevalent among adolescents than among women in their 20s; in settings where sexual activity is low among adolescents, abortion rates might also be low. ${ }^{6}$

Other factors that could influence the age patterns of abortion include age at marriage, desired fertility and fecundity. The average age at marriage has been increasing in many countries, ${ }^{7,8}$ and the risk of unintended pregnancy and abortion among sexually active women in their 20s may also be increasing. Women who are reaching the end of their reproductive years, are sexually active and fecund, and have completed their desired family size are also at risk of unintended pregnancy and abortion.

The most recent prior assessments of abortion incidence across age-groups of women are for the mid-1990s and for 2003; 3,9 however, patterns in age-specific abortion levels in many countries may have changed since then. Thus, we sought the most recent available statistics on 


\begin{tabular}{|c|c|c|c|c|c|c|c|c|c|c|}
\hline Country & Year & $<20$ & $15-17$ & $18-19$ & $20-24$ & $25-29$ & $30-34$ & $35-39$ & $\geq 40$ & Total \\
\hline \multicolumn{11}{|c|}{ Complete statistics } \\
\hline \multirow[t]{3}{*}{ Belgium } & 1995 & 14 & $\mathrm{u}$ & u & 25 & 23 & 20 & 13 & 5 & 100 \\
\hline & 2003 & 14 & $\mathrm{u}$ & u & 26 & 22 & 19 & 14 & 6 & 100 \\
\hline & 2009 & 14 & $\mathrm{u}$ & u & 25 & 23 & 19 & 13 & 5 & 100 \\
\hline \multirow{3}{*}{ Czech Republic } & 1996 & 11 & $\mathrm{u}$ & u & 25 & 23 & 21 & 13 & 8 & 100 \\
\hline & 2003 & 9 & $\mathrm{u}$ & u & 19 & 26 & 22 & 16 & 8 & 100 \\
\hline & 2009 & 9 & $\mathrm{u}$ & u & 18 & 20 & 25 & 19 & 8 & 100 \\
\hline \multirow[t]{3}{*}{ Denmark } & 1995 & 13 & 5 & 8 & 23 & 24 & 21 & 13 & 6 & 100 \\
\hline & 2003 & 13 & $\mathrm{u}$ & u & 20 & 21 & 21 & 18 & 7 & 100 \\
\hline & 2010 & 16 & $\mathrm{u}$ & u & 25 & 18 & 18 & 15 & 7 & 100 \\
\hline \multirow[t]{3}{*}{ England/Wales } & 1996 & 19 & 9 & 10 & 28 & 23 & 17 & 10 & 3 & 100 \\
\hline & 2003 & 21 & $\mathrm{u}$ & $\mathrm{u}$ & 28 & 20 & 16 & 11 & 4 & 100 \\
\hline & 2010 & 20 & $\mathrm{u}$ & u & 29 & 22 & 15 & 10 & 4 & 100 \\
\hline \multirow[t]{3}{*}{ Estonia } & 1996 & 10 & $\mathrm{u}$ & u & 26 & 24 & 19 & 15 & 7 & 100 \\
\hline & 2003 & 14 & 5 & 9 & 24 & 22 & 19 & 14 & 7 & 100 \\
\hline & 2010 & 10 & 3 & 7 & 25 & 23 & 19 & 16 & 7 & 100 \\
\hline \multirow[t]{3}{*}{ Finland } & 1996 & 17 & $\mathrm{u}$ & u & 22 & 22 & 20 & 13 & 6 & 100 \\
\hline & 2003 & 22 & $\mathrm{u}$ & u & 25 & 18 & 15 & 14 & 5 & 100 \\
\hline & 2010 & 19 & $\mathrm{u}$ & u & 26 & 21 & 16 & 11 & 6 & 100 \\
\hline France & $1996^{*}, \dagger$ & 13 & 5 & 8 & 24 & 22 & 20 & 14 & 6 & 100 \\
\hline & 2003 & 13 & 5 & 8 & 25 & 21 & 19 & 14 & 7 & 100 \\
\hline & 2009 & 14 & 6 & 8 & 25 & 22 & 17 & 14 & 7 & 100 \\
\hline Germany & 1995 & 7 & $\mathrm{u}$ & u & 18 & 26 & 25 & 17 & 8 & 100 \\
\hline & 2003 & 13 & 6 & 7 & 23 & 21 & 20 & 16 & 7 & 100 \\
\hline & 2009 & 12 & 4 & 7 & 24 & 23 & 19 & 15 & 8 & 100 \\
\hline Hungary & 1996 & 15 & 6 & 9 & 25 & 22 & 17 & 14 & 7 & 100 \\
\hline & 2003 & 12 & $\mathrm{u}$ & u & 22 & 26 & 21 & 14 & 6 & 100 \\
\hline & 2009 & 12 & $\mathrm{u}$ & u & 20 & 21 & 24 & 17 & 7 & 100 \\
\hline Iceland & 1996 & 25 & $\mathrm{u}$ & u & 27 & 19 & 13 & 12 & 4 & 100 \\
\hline & 2000 & 27 & $\mathrm{u}$ & u & 24 & 21 & 13 & 9 & 5 & 100 \\
\hline & 2009 & 14 & $\mathrm{u}$ & u & 27 & 25 & 16 & 11 & 7 & 100 \\
\hline Israel & 2003 & 15 & $\mathrm{u}$ & u & 21 & 21 & 20 & 15 & 9 & 100 \\
\hline & 2009 & 13 & $\mathrm{u}$ & u & 21 & 20 & 20 & 17 & 9 & 100 \\
\hline Italy & $1995^{*}$ & 8 & $\mathrm{u}$ & $\mathrm{u}$ & 20 & 23 & 23 & 18 & 9 & 100 \\
\hline & 2003 & 8 & $\mathrm{u}$ & u & 19 & 23 & 22 & 18 & 8 & 100 \\
\hline & 2009 & 9 & $\mathrm{u}$ & u & 18 & 21 & 23 & 20 & 10 & 100 \\
\hline Netherlands & 1996 & 11 & $\mathrm{u}$ & u & 22 & 25 & 22 & 15 & 6 & 100 \\
\hline & 2003 & 14 & $\mathrm{u}$ & u & 24 & 21 & 20 & 15 & 6 & 100 \\
\hline & 2008 & 12 & $\mathrm{u}$ & $\mathrm{u}$ & 26 & 21 & 18 & 16 & 7 & 100 \\
\hline New Zealand & 1995 & 19 & $\mathrm{u}$ & u & 31 & 22 & 16 & 9 & 3 & 100 \\
\hline & 2003 & 21 & $\mathrm{u}$ & $\mathrm{u}$ & 31 & 20 & 15 & 10 & 4 & 100 \\
\hline & 2010 & 21 & $\mathrm{u}$ & u & 31 & 21 & 13 & 10 & 4 & 100 \\
\hline Norway & 1996 & 14 & $\mathrm{u}$ & $\mathrm{u}$ & 27 & 25 & 18 & 11 & 5 & 100 \\
\hline & 2003 & 16 & $\mathrm{u}$ & u & 26 & 21 & 19 & 13 & 5 & 100 \\
\hline & 2011 & 13 & $\mathrm{u}$ & u & 29 & 23 & 17 & 13 & 6 & 100 \\
\hline Portugal & 2009 & 12 & $\mathrm{u}$ & u & 21 & 22 & 21 & 16 & 7 & 100 \\
\hline Scotland & 1995‡ & 22 & $\mathrm{u}$ & u & 31 & 22 & 15 & 8 & 3 & 100 \\
\hline & 2003 & 25 & $\mathrm{u}$ & u & 30 & 18 & 14 & 9 & 4 & 100 \\
\hline & 2010 & 24 & $\mathrm{u}$ & u & 31 & 20 & 13 & 9 & 3 & 100 \\
\hline Singapore & 1996 & 10 & $\mathrm{u}$ & u & 23 & 21 & 21 & 18 & 7 & 100 \\
\hline & 2004 & 11 & $\mathrm{u}$ & u & 26 & 22 & 19 & 15 & 7 & 100 \\
\hline & 2010 & 9 & $\mathrm{u}$ & u & 24 & 26 & 20 & 15 & 6 & 100 \\
\hline Slovakia & 1995 & 9 & $\mathrm{u}$ & u & 23 & 24 & 22 & 15 & 7 & 100 \\
\hline & 2003 & 9 & 3 & 6 & 21 & 25 & 22 & 16 & 7 & 100 \\
\hline & 2009 & 8 & $\mathrm{u}$ & u & 18 & 23 & 25 & 18 & 8 & 100 \\
\hline Slovenia & 1996 & 8 & 2 & 5 & 18 & 19 & 24 & 20 & 11 & 100 \\
\hline & 2003 & 8 & 3 & 5 & 19 & 22 & 21 & 21 & 10 & 100 \\
\hline & 2010 & 8 & 2 & 5 & 17 & 21 & 24 & 20 & 10 & 100 \\
\hline Spain & $1996^{*}$ & 14 & $\mathrm{u}$ & u & 27 & 22 & 18 & 13 & 6 & 100 \\
\hline & 2003 & 14 & $\mathrm{u}$ & u & 27 & 24 & 18 & 12 & 5 & 100 \\
\hline & 2010 & 12 & $\mathrm{u}$ & u & 23 & 24 & 21 & 14 & 6 & 100 \\
\hline Sweden & 1996 & 14 & 6 & 7 & 24 & 23 & 20 & 13 & 6 & 100 \\
\hline & 2002 & 19 & $\mathrm{u}$ & $\mathrm{u}$ & 23 & 19 & 18 & 15 & 6 & 100 \\
\hline & 2009 & 19 & $\mathrm{u}$ & u & 26 & 19 & 16 & 13 & 7 & 100 \\
\hline United States & 1996 & 20 & 8 & 12 & 32 & 23 & 14 & 8 & 2 & 100 \\
\hline & 2000 & 19 & 7 & 12 & 33 & 23 & 14 & 8 & 3 & 100 \\
\hline & 2008 & 18 & 7 & 11 & 33 & 24 & 14 & 8 & 3 & 100 \\
\hline Incomplete stat & & & & & & & & & & \\
\hline Armenia & 2003 & 0 & 0 & 0 & 14 & 57 & 16 & 13 & 1 & 100 \\
\hline & 2008 & 0 & 0 & 0 & 23 & 40 & 26 & 10 & 0 & 100 \\
\hline Belarus & 1996 & 8 & u & u & 26 & 26 & 21 & 14 & 6 & 100 \\
\hline & $2003 \S$ & 10 & u & u & 26 & 25 & 20 & 14 & 7 & 100 \\
\hline & 2009 & 9 & $\mathrm{u}$ & $u$ & 23 & 26 & 20 & 14 & 7 & 100 \\
\hline
\end{tabular}




\begin{tabular}{|c|c|c|c|c|c|c|c|c|c|c|}
\hline Country & Year & $<20$ & $15-17$ & $18-19$ & $20-24$ & $25-29$ & $30-34$ & $35-39$ & $\geq 40$ & Total \\
\hline \multicolumn{11}{|c|}{ Incomplete statistics (cont.) } \\
\hline \multirow[t]{3}{*}{ Canada } & $1995 \S$ & 20 & 7 & 12 & 30 & 22 & 16 & 10 & 3 & 100 \\
\hline & $2003 \S$ & 17 & u & u & 31 & 21 & 15 & 10 & 4 & 100 \\
\hline & $2009^{* *}$ & 18 & u & u & 30 & 23 & 15 & 15 & u & 100 \\
\hline \multirow{3}{*}{ Croatia } & 1996 & 6 & u & u & 17 & 20 & 25 & 22 & 11 & 100 \\
\hline & 2003 & 9 & 1 & 7 & 18 & 20 & 22 & 22 & 10 & 100 \\
\hline & 2008 & 8 & 1 & 7 & 19 & 22 & 20 & 20 & 11 & 100 \\
\hline Cuba & $2009+\dagger$ & 29 & u & $\mathrm{u}$ & 57 & $\mathrm{u}$ & u & 13 & u & 100 \\
\hline \multirow[t]{2}{*}{ Georgia } & $2003 \neq \neq$ & 6 & $\mathrm{u}$ & $\mathrm{u}$ & 53 & u & 37 & u & 4 & 100 \\
\hline & $2008 \neq \neq$ & 6 & u & u & 50 & u & 38 & u & 7 & 100 \\
\hline \multirow[t]{2}{*}{ Hong Kong } & 2003 & 9 & u & u & 22 & 22 & 19 & 18 & 10 & 100 \\
\hline & 2009 & 9 & $\mathrm{u}$ & $\mathrm{u}$ & 21 & 21 & 19 & 18 & 11 & 100 \\
\hline \multirow[t]{3}{*}{ Japan } & 1995 & 8 & $u$ & u & 23 & 19 & 20 & 19 & 11 & 100 \\
\hline & 2003 & 13 & u & u & 24 & 21 & 20 & 15 & 7 & 100 \\
\hline & 2009 & 9 & $\mathrm{u}$ & $\mathrm{u}$ & 23 & 21 & 20 & 18 & 8 & 100 \\
\hline \multirow[t]{3}{*}{ Kazakhstan } & $1995 \S$ & 5 & $\mathrm{u}$ & u & 22 & 30 & 23 & 15 & 6 & 100 \\
\hline & $2003 \S \S$ & 5 & u & u & 75 & $\mathrm{u}$ & $\mathrm{u}$ & 20 & u & 100 \\
\hline & $2008 \S \S$ & 4 & u & u & 76 & $\mathrm{u}$ & u & 20 & u & 100 \\
\hline \multirow[t]{2}{*}{ Kyrgyzstan } & 1997 & 2 & u & $\mathrm{u}$ & 20 & 24 & 30 & 18 & 7 & 100 \\
\hline & 2008 & 9 & u & u & 24 & 26 & 22 & 13 & 5 & 100 \\
\hline \multirow[t]{3}{*}{ Latvia } & $1996 \S_{,}^{*}+$ & 10 & 3 & 8 & 69 & $\mathrm{u}$ & u & 20 & u & 100 \\
\hline & $2003 \S$ & 11 & 3 & 8 & 24 & 23 & 21 & 15 & 7 & 100 \\
\hline & 2009 & 9 & u & u & 23 & 23 & 20 & 17 & 8 & 100 \\
\hline \multirow{2}{*}{ Lithuania } & 2003 & 8 & $\mathrm{u}$ & u & 21 & 23 & 23 & 17 & 8 & 100 \\
\hline & 2010 & 7 & 2 & 5 & 20 & 22 & 21 & 19 & 10 & 100 \\
\hline \multirow[t]{2}{*}{ Mongolia } & $2003^{*} \neq$ & 8 & u & u & 66 & u & u & 26 & u & 100 \\
\hline & 2008 & 7 & $\mathrm{u}$ & u & 22 & 23 & 22 & 17 & 8 & 100 \\
\hline Puerto Rico & 2006 & 18 & $\mathrm{u}$ & u & 34 & 26 & 14 & 6 & 3 & 100 \\
\hline \multirow{2}{*}{ Romania } & $1993^{* *}$ & 5 & $\mathrm{u}$ & u & 28 & 27 & 25 & 15 & u & 100 \\
\hline & 2008 & 12 & $\mathrm{u}$ & $\mathrm{u}$ & 22 & 22 & 22 & 17 & 6 & 100 \\
\hline \multirow{3}{*}{ Russian Federation } & $1996 * \S$ & 7 & $\mathrm{u}$ & $\mathrm{u}$ & 27 & 49 & $\mathrm{u}$ & 17 & $\mathrm{u}$ & 100 \\
\hline & $2003 \S_{,}^{*} \neq$ & 10 & $\mathrm{u}$ & u & 71 & u & u & 19 & $\mathrm{u}$ & 100 \\
\hline & 2010 & 7 & $\mathrm{u}$ & $\mathrm{u}$ & 25 & 27 & 22 & 15 & 6 & 100 \\
\hline \multirow[t]{2}{*}{ Serbia } & $2003 t^{*}$ & 3 & u & $\mathrm{u}$ & 14 & 48 & u & 34 & 1 & 100 \\
\hline & 2010 & 4 & 1 & 3 & 14 & 22 & 26 & 23 & 11 & 100 \\
\hline South Africa & $2009+\neq$ & 15 & u & u & 85 & u & u & u & u & 100 \\
\hline \multicolumn{11}{|l|}{ Surveyst§ } \\
\hline Albania & $2008 / 2009 \neq^{*}$ & 3 & $\mathrm{u}$ & $\mathrm{u}$ & 11 & 34 & 24 & 21 & 7 & 100 \\
\hline \multirow[t]{2}{*}{ Cambodia } & 2005抿 & 4 & u & u & 20 & 18 & 26 & 18 & 14 & 100 \\
\hline & $2010 \neq \dagger$ & 4 & $\mathrm{u}$ & u & 19 & 24 & 19 & 21 & 13 & 100 \\
\hline \multicolumn{11}{|c|}{ Surveys/incomplete statistics } \\
\hline Azerbaijan (statistics) & $2007^{* *}$ & 5 & $\mathrm{u}$ & $\mathrm{u}$ & 22 & 31 & 24 & 17 & $\mathrm{u}$ & 100 \\
\hline Azerbaijan (survey) & $2006 \ddagger^{*}$ & 2 & $\mathrm{u}$ & u & 17 & 27 & 26 & 19 & 9 & 100 \\
\hline Ukraine (statistics) & $2003 * \dagger$ & 11 & 3 & 9 & 72 & $\mathrm{u}$ & u & 17 & u & 100 \\
\hline Ukraine (statistics) & $2009 * \dagger$ & 8 & 2 & 7 & 74 & $\mathrm{u}$ & u & 18 & u & 100 \\
\hline Ukraine (survey) & $2007 \#^{*}$ & 6 & u & $\mathrm{u}$ & 21 & 31 & 22 & 14 & 6 & 100 \\
\hline
\end{tabular}

the level of legal abortion according to women's age in all countries and major territories with liberal abortion laws, or where abortion laws are interpreted liberally so that legal abortion is generally available. We present the available information from such countries, as well as subregional and regional estimates of the age-pattern of abortion for geographic areas where the national data represent the majority of the population.*

\section{METHODS}

\section{Data Collection}

For all countries and major territories with liberal abortion laws, we obtained statistics on the number of legal abortions by the woman's age at the time of the abortion ${ }^{\dagger}$ for the most recent year available after 2003. We considered a country or territory to have liberal abortion laws if abortion there is legal without restriction as to reason or if it is legal on socioeconomic grounds, either with or without gestational limits. Nearly all, if not all, abortions performed in countries with liberal abortion laws are legal; exceptions include, for example, abortions performed after the legally allowed gestational limit. ${ }^{10}$ We also obtained information for countries whose laws allow for abortion to preserve the physical or mental health of the woman, if these laws are

*We employed the United Nations definition of regions and subregions. †For a few countries, we were able to obtain age-specific abortion rates or the distribution of abortions by age, but not the absolute numbers of abortions. 
FIGURE 1. Percentage of all abortions obtained by females younger than 20 , by country

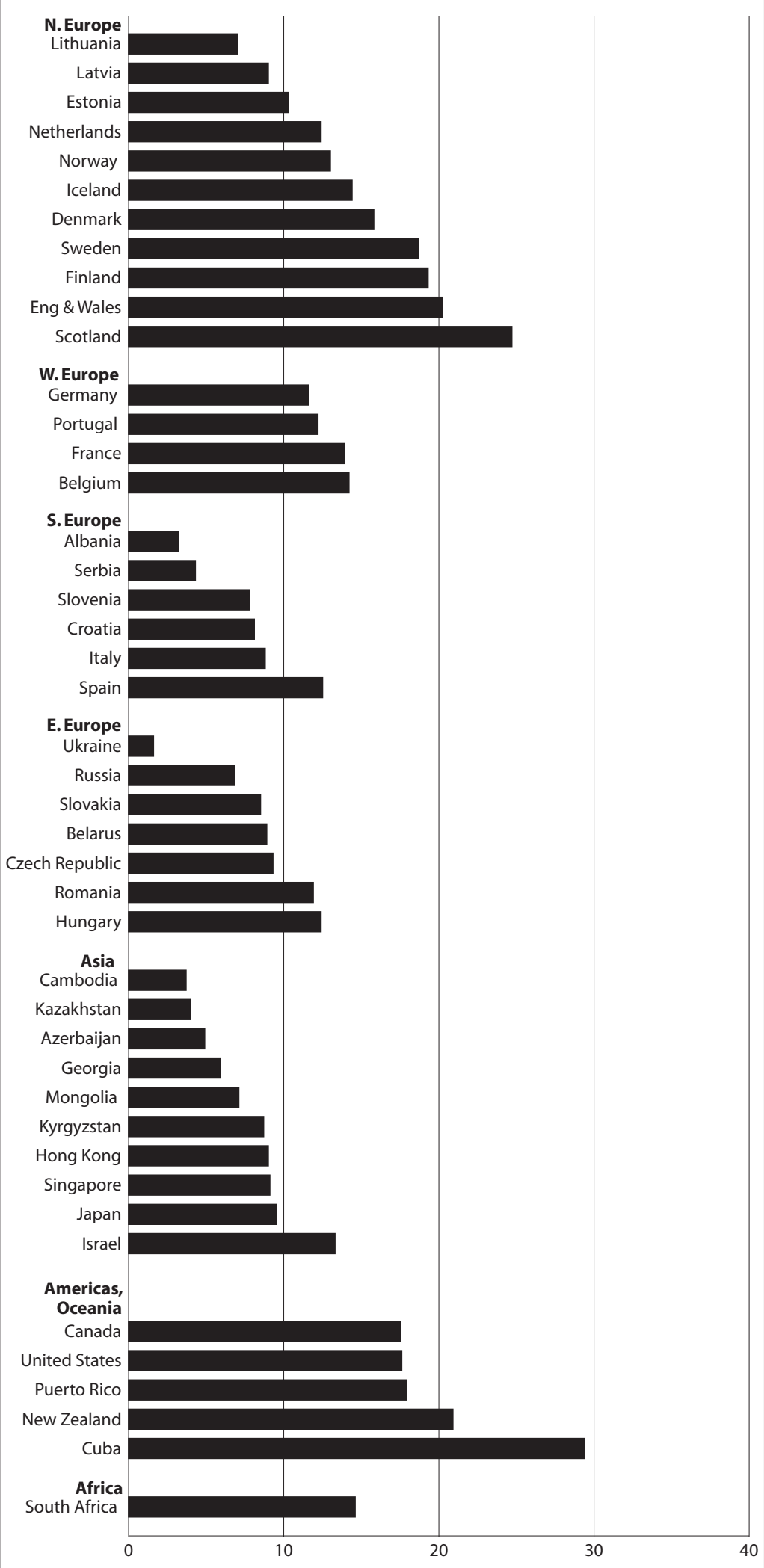

Note: Data are based on country data for the most recent year available; median year of all data was 2009. interpreted liberally, so that most abortions are deemed legal. To the best of our knowledge, 78 countries and territories fall into these categories. ${ }^{11}$

Data collection on the age patterns of abortion occurred in conjunction with data collection on national abortion incidence, conducted in 2010. ${ }^{2}$ We started by searching Web sites of statistical offices or relevant agencies for official abortion data. If such data could not be found online, we contacted agencies directly and asked representatives to complete a standardized questionnaire on the incidence of legally induced abortions each year from 2003 to 2008 by selected characteristics of women, including age. If direct inquiries did not yield a response, we attempted to identify and solicit other informants with access to the information, primarily through Web searches and with the help of local contacts. In February and March of 2012, we followed up with country sources and obtained more recent data where available. In addition, the United Nations Statistics Division (UNSD) Demographic Yearbook periodically publishes national numbers of legal abortions performed, by women's age and number of previous live births. ${ }^{12}$ If these numbers corresponded with the figures we obtained from direct contacts in 2008, and the Demographic Yearbook had statistics more recent than those we had obtained directly, we present the most recent abortion figures available from the UNSD.

We ascertained the coverage of official reports through inquiries to representatives of reporting agencies who provided data. If the completeness of reports was in question or unknown, we also sought assessments from experts, including demographers, statisticians, national and regional specialists in sexual and reproductive health, policy advisors and providers familiar with abortion reporting procedures in the country. On the basis of this information, we classified countries according to whether their abortion data were complete (defined as including at least 90\% of all legal abortions), likely to be incomplete or of unknown completeness. In some countries, the completeness classification changed over time. We included countries with complete data for the most recent year available in the group of countries with complete statistics. If trend data are shown, we indicate if data completeness changed over time.

In addition, we present abortion estimates, if available, from nationally representative surveys of women in countries with liberal abortion laws. The surveys do not distinguish between legal procedures and illegal procedures. Survey-based estimates are generally considered to be incomplete, because the level of underreporting of abortion in surveys is often high, particularly for those based on face-to-face interviews. According to studies that have attempted to validate findings, underreporting ranges from $15 \%$ to $69 \%$ in countries with liberal abortion laws. ${ }^{13}$ For a few countries, both official statistics and survey-based estimates of abortions by age are available. Although neither source represents a gold standard, taken together, they can provide a better understanding of the association between 
abortion incidence and age.

To calculate age-specific abortion rates for each country on the basis of reported numbers of abortions, we obtained estimates of the population of women aged 15-44 by five-year age-group from the UNSD Demographic Yearbook, which compiles information from countries' official statistical authorities. ${ }^{14}$ We interpolated where necessary to obtain population estimates for the year corresponding to the abortion statistics. The calculation of age-specific rates assumes that the UN estimates of population by age-group are accurate.

In our calculations of percentage distributions of abortion, we had sources of abortion information for 45 countries: We used complete official records for 23 countries, incomplete official records for 18 , survey-based estimates for two, and incomplete records and survey estimates for two. In our calculations of abortion rate, we had sources of abortion information for 43 countries: We used complete official records for 21 countries, incomplete official records for 18 , survey-based estimates for one, and incomplete records and survey-based estimates for three.

To examine abortion trends over time, we relied primarily on previously published information on abortions by age..$^{3,9,15}$ If published statistics for the earlier time periods were not available, we turned to the official reports from relevant agencies and data that had been collected previously in questionnaires administered to reporting agencies, as described above. In some cases, the total number of abortions reported by the UNSD matched the total provided by government sources for earlier time periods, and the UNSD was the only source of detail on abortions according to the woman's age; in these cases, data from the UNSD on the number of abortions by woman's age are presented.
TABLE 2. Percentage distribution of legal abortions, by woman's age at termination, according to region and subregion

\begin{tabular}{|c|c|c|c|c|c|c|c|c|}
\hline \multirow{2}{*}{$\begin{array}{l}\text { Region/ } \\
\text { subregion }\end{array}$} & \multirow{2}{*}{$\begin{array}{l}\% \text { of region } \\
\text { represented } \\
\text { by data }\end{array}$} & \multicolumn{7}{|c|}{$\%$ distribution } \\
\hline & & $<20$ & $20-24$ & $25-29$ & $30-34$ & $35-39$ & $\geq 40$ & Total \\
\hline North America & 100 & 18 & 33 & 24 & 14 & $11^{*}$ & $u$ & 100 \\
\hline Europe & 81 & 11 & 24 & 24 & 20 & 15 & 7 & 100 \\
\hline Northern & 95 & 18 & 28 & 21 & 16 & 11 & 5 & 100 \\
\hline Western & 91 & 13 & 25 & 22 & 18 & 15 & 7 & 100 \\
\hline Southern & 85 & 10 & 20 & 22 & 22 & 18 & 8 & 100 \\
\hline Eastern & 68 & 8 & 23 & 26 & 22 & 15 & 6 & 100 \\
\hline Eastern Asia† & 54 & 9 & 23 & 22 & 20 & 18 & 8 & 100 \\
\hline
\end{tabular}

*Includes abortions among women aged 35-44. tExcluding China. Notes: u=unavailable. Data are based on country data for the most recent year available; median year of all data was 2009.

\section{Analysis}

We calculated the age-specific abortion rate for each agegroup as (abortions in age-group/female population in age-group) x 1,000. We used the age-specific rates to compute the total abortion rate (TAR), or the number of abortions a woman would be expected to have over a lifetime at current age-specific rates, as $\Sigma($ ASAR x 5)/1,000, where the ASARs are age-specific abortion rates in five-year agegroups for females aged 15-44.

We examined two measures of how abortion incidence varies by women's age: the percentage distribution of abortions and the abortion rate. Incomplete reporting affects these two measures differently. The percentage distribution of abortions can be reasonably accurate even in settings where abortions are underreported, as long as the level of underreporting does not vary by age. In contrast, high levels of underreporting will compromise the accuracy of agespecific abortion rates. As long as the level of underreporting is similar across age-groups, however, the age-specific abortion rates are useful because they allow us to compare

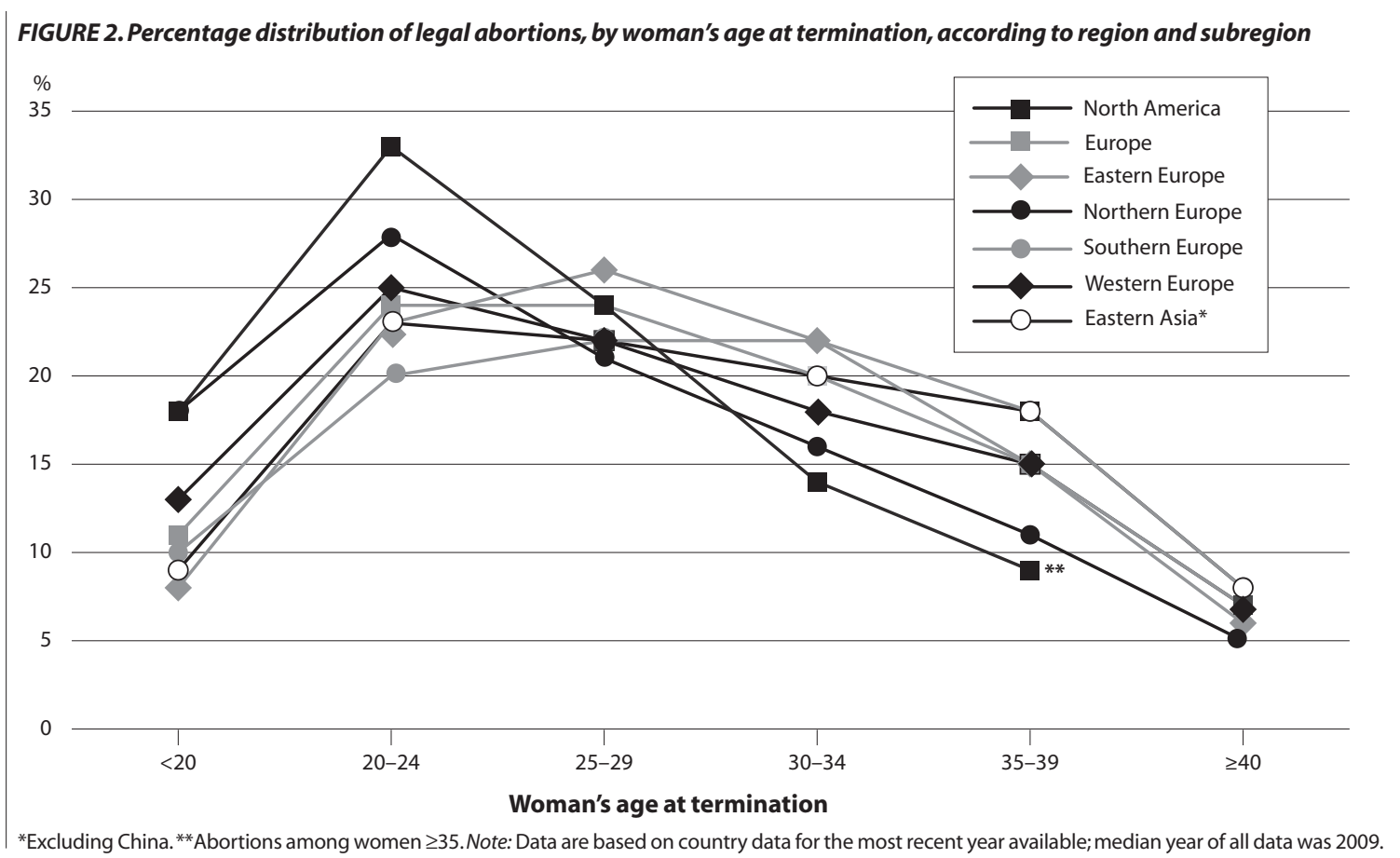


TABLE 3. Abortion rate and total abortion rate, by woman's age at termination,
according to selected countries and years

\begin{tabular}{|c|c|c|c|c|c|c|c|c|}
\hline Country & Year & $15-19$ & $20-24$ & $25-29$ & $30-34$ & $35-39$ & $\geq 40$ & $\begin{array}{l}\text { Total abor- } \\
\text { tion rate* }\end{array}$ \\
\hline \multicolumn{9}{|c|}{ Complete statistics } \\
\hline \multirow[t]{3}{*}{ Belgium } & 1995 & 6.2 & 10.1 & 8.4 & 6.7 & 4.5 & 1.7 & 0.19 \\
\hline & 2003 & 7.3 & 12.6 & 10.5 & 8.2 & 5.4 & 2.2 & 0.23 \\
\hline & 2008 & 8.4 & 14.5 & 12.7 & 10.1 & 6.7 & 2.4 & 0.27 \\
\hline \multirow{3}{*}{ Denmark } & 1995 & 15.0 & 23.0 & 21.0 & 20.0 & 13.0 & 6.0 & 0.49 \\
\hline & 2003 & 14.8 & 21.0 & 18.1 & 17.2 & 13.4 & 5.2 & 0.45 \\
\hline & 2010 & 15.0 & 25.6 & 19.5 & 17.1 & 13.0 & 5.3 & 0.48 \\
\hline \multirow[t]{3}{*}{ England/Wales } & 1996 & 22.0 & 28.0 & 20.0 & 14.0 & 9.0 & 3.0 & 0.48 \\
\hline & 2003 & 23.0 & 31.0 & 22.0 & 15.0 & 10.0 & 4.0 & 0.53 \\
\hline & 2010 & 22.0 & 30.2 & 22.5 & 16.5 & 10.0 & 4.0 & 0.53 \\
\hline \multirow{3}{*}{ Estonia } & 1996 & 43.0 & 93.0 & 83.0 & 63.0 & 43.0 & 19.0 & 1.72 \\
\hline & 2003 & 28.3 & 52.6 & 51.0 & 43.3 & 32.2 & 14.0 & 1.11 \\
\hline & 2010 & 19.2 & 33.5 & 32.1 & 29.2 & 23.8 & 10.9 & 0.74 \\
\hline \multirow{3}{*}{ Finland } & 1996 & 11.4 & 15.0 & 14.0 & 11.0 & 7.0 & 3.0 & 0.31 \\
\hline & 2003 & 15.3 & 17.0 & 12.3 & 10.7 & 8.0 & 2.9 & 0.33 \\
\hline & 2010 & 12.1 & 17.0 & 13.0 & 9.8 & 7.7 & 3.0 & 0.31 \\
\hline \multirow[t]{2}{*}{ France } & 2003 & 14.4 & 26.7 & 22.3 & 18.2 & 13.0 & 5.6 & 0.50 \\
\hline & 2009 & 15.2 & 26.7 & 23.4 & 18.8 & 13.6 & 5.8 & 0.52 \\
\hline \multirow[t]{3}{*}{ Germany } & 1995 & 6.0 & 11.0 & 11.0 & 9.0 & 7.0 & 3.0 & 0.24 \\
\hline & 2003 & 7.0 & 13.0 & 11.0 & 9.0 & 6.0 & 3.0 & 0.25 \\
\hline & 2009 & 5.9 & 11.2 & 10.3 & 9.1 & 5.9 & 2.3 & 0.22 \\
\hline \multirow[t]{3}{*}{ Hungary } & 1996 & 30.0 & 47.0 & 49.0 & 44.0 & 31.0 & 13.0 & 1.07 \\
\hline & 2003 & 20.0 & 33.0 & 33.0 & 31.0 & 24.0 & 9.0 & 0.75 \\
\hline & 2009 & 18.0 & 26.9 & 25.6 & 24.6 & 19.7 & 8.0 & 0.61 \\
\hline Iceland & 1996 & 20.6 & 22.4 & 16.8 & 10.2 & 9.9 & 3.1 & 0.42 \\
\hline & 2003 & 19.2 & 23.6 & 16.5 & 17.0 & 10.2 & 4.7 & 0.46 \\
\hline & 2009 & 12.0 & 23.2 & 20.3 & 13.9 & 10.1 & 5.2 & 0.42 \\
\hline Israel & 1996 & 10.3 & 16.2 & 16.4 & 16.3 & 15.1 & 8.8 & 0.42 \\
\hline & 2003 & 10.7 & 15.0 & 15.3 & 16.2 & 14.6 & 8.5 & 0.40 \\
\hline & 2009 & 9.1 & 14.8 & 13.9 & 14.6 & 13.6 & 7.2 & 0.37 \\
\hline Italy & 2003 & 7.0 & 15.0 & 14.0 & 12.0 & 10.0 & 5.0 & 0.32 \\
\hline & 2009 & 6.9 & 13.8 & 13.4 & 12.2 & 9.6 & 4.2 & 0.30 \\
\hline Netherlands & 1996 & 5.3 & 9.3 & 8.9 & 7.6 & 5.4 & 2.4 & 0.19 \\
\hline & 2003 & 9.0 & 14.0 & 12.0 & 9.0 & 7.0 & 3.0 & 0.27 \\
\hline & 2008 & 7.1 & 15.0 & 12.2 & 9.7 & 7.0 & 3.5 & 0.27 \\
\hline New Zealand & 1995 & 22.0 & 31.0 & 23.0 & 15.0 & 9.0 & 4.0 & 0.52 \\
\hline & 2003 & 25.9 & 41.1 & 27.9 & 18.0 & 11.6 & 4.3 & 0.64 \\
\hline & 2010 & 21.6 & 33.4 & 23.4 & 16.0 & 10.4 & 4.0 & 0.54 \\
\hline Norway & 1996 & 16.0 & 26.0 & 21.0 & 16.0 & 10.0 & 4.0 & 0.47 \\
\hline & 2003 & 16.0 & 27.0 & 19.0 & 15.0 & 11.0 & 4.0 & 0.46 \\
\hline & 2011 & 12.7 & 27.6 & 22.6 & 16.6 & 11.3 & 4.4 & 0.48 \\
\hline Portugal & 2009 & 7.1 & 10.7 & 10.8 & 10.9 & 7.8 & 3.8 & 0.26 \\
\hline Scotland & 1995 & 16.6 & 19.5 & 12.4 & 8.0 & 4.8 & 2.0 & 0.32 \\
\hline & 2003 & 19.6 & 23.0 & 15.2 & 9.3 & 5.4 & 2.2 & 0.37 \\
\hline & 2010 & 19.6 & 22.5 & 15.1 & 10.7 & 6.6 & 2.2 & 0.38 \\
\hline Slovakia & 1995 & 11.1 & 31.5 & 38.8 & 32.7 & 21.4 & 8.9 & 0.72 \\
\hline & 2003 & 7.2 & 14.8 & 18.3 & 18.7 & 13.5 & 6.1 & 0.39 \\
\hline & 2008 & 6.3 & 12.0 & 13.3 & 14.6 & 12.1 & 5.6 & 0.32 \\
\hline Slovenia & 1996 & 11.0 & 26.0 & 28.0 & 32.0 & 27.0 & 15.0 & 0.70 \\
\hline & 2003 & 9.0 & 18.0 & 21.0 & 21.0 & 16.0 & 7.0 & 0.46 \\
\hline & 2010 & 6.6 & 11.9 & 12.7 & 14.1 & 12.3 & 5.6 & 0.32 \\
\hline Spain & 2003 & 9.9 & 15.3 & 11.3 & 8.3 & 6.0 & 2.7 & 0.27 \\
\hline & 2010 & 12.7 & 19.8 & 16.3 & 12.1 & 8.3 & 3.5 & 0.36 \\
\hline Sweden & 1996 & 17.8 & 27.8 & 24.9 & 20.7 & 14.9 & 6.5 & 0.56 \\
\hline & 2003 & 24.4 & 31.0 & 23.9 & 20.5 & 15.6 & 7.3 & 0.61 \\
\hline & 2010 & 20.9 & 33.3 & 26.7 & 21.5 & 16.3 & 7.9 & 0.63 \\
\hline United States & 1996 & 29.7 & 49.3 & 32.1 & 17.7 & 9.7 & 3.2 & 0.71 \\
\hline & 2003 & 22.0 & 43.0 & 31.0 & 19.0 & 10.0 & 4.0 & 0.65 \\
\hline & 2008 & 19.8 & 39.9 & 28.6 & 17.1 & 9.5 & 3.2 & 0.59 \\
\hline Incomplete stat & & & & & & & & \\
\hline Belarus & 2009 & 10.1 & 20.8 & 24.5 & 21.1 & 15.0 & 6.1 & 0.49 \\
\hline Canadat, $\neq$ & 2009 & 15.0 & 24.8 & 18.2 & 12.8 & 5.7 & $\mathrm{u}$ & 0.41 \\
\hline Croatia§ & 2008 & 2.8 & 5.9 & 6.3 & 6.0 & 6.0 & 2.8 & 0.15 \\
\hline Cuba** & 2009 & 63.9 & 44.3 & u & u & 10.9 & $\mathrm{u}$ & 1.09 \\
\hline Czech Republic & 2009 & 7.5 & 13.0 & 13.3 & 13.6 & 12.0 & 5.9 & 0.33 \\
\hline Georgiatt & 2008 & 6.3 & 27.5 & u & 22.9 & u & 8.3 & 0.58 \\
\hline Hong Kong & 2009 & 5.0 & 10.8 & 8.4 & 7.3 & 6.6 & 3.5 & 0.21 \\
\hline Japan & 2009 & 7.1 & 14.9 & 13.0 & 10.5 & 8.6 & 3.8 & 0.29 \\
\hline Kyrgyzstan & 2008 & 6.2 & 18.0 & 24.7 & 24.1 & 15.8 & 6.2 & 0.48 \\
\hline Latvia & 2009 & 10.9 & 22.7 & 24.3 & 23.2 & 18.7 & 8.2 & 0.54 \\
\hline
\end{tabular}

rates across groups of women.

When we identified exceptionally high age-specific rates, we included those based on incomplete statistics and surveys. When we identified exceptionally low rates, we excluded those based on these sources of information because underreporting can lead to the erroneous impression that rates are low.

Some variation in the quality of reporting by age-group could exist if, for example, younger women are more likely to seek out clandestine services, or older women are better able to afford services from private providers in countries where private providers are not required to report procedures. We assume that most of these potential influences on reporting by age cancel each other out and that any remaining differentials in reporting by age are small.

When abortions were reported but the woman's age was not specified, we assumed the distribution across agegroups was the same as among cases where age was reported. The countries with the largest numbers of such cases were Canada and the Russian Federation (10\% and 5\% of all abortions, respectively). For some countries, very small numbers of abortions among females younger than 15 or older than 44 were reported; these were classified with abortions among females $15-19$ and 40-44, respectively.

The median year for the most recent estimates of abortions by women's age is 2009 and ranges from 2006 to 2010. For countries with complete reporting across time periods, we assessed trends in the age distribution of abortions and age-specific abortion rates by comparing the most recent figures with measures for 1996 (or the closest year with reliable information) and 2003 (or the closest year). We selected these time periods because the completeness and quality of the corresponding abortion statistics have already been assessed and reviewed, and because many of these statistics have already been published. 3,9,15

For subregions with information on the distribution of legal abortions by women's age for more than $50 \%$ of the population of females aged 15-44, the age distribution of abortions was estimated as the weighted average of the distributions in the countries for which information was available, with the populations of females aged 15-44 in the countries in 2009 serving as weights. For two major regions, North America and Europe, data on distributions of abortions by age were available for $100 \%$ and $81 \%$ of the populations, respectively. We computed the distribution of abortions by age in North America as the weighted average of the distributions in United States and Canada. The proportion of abortions by age in Europe was estimated as the weighted average of the subregional proportions, and the size of the female population in the subregions served as the weights.

\section{RESULTS}

\section{Distribution of Abortion by Age}

Of the 45 countries with information on the distribution of abortions by age, 40 classified women in five-year agegroups at least through age 34 in the most recent year for 
which data were available.* For 18 of these, the greatest proportion of abortions that year occurred among women aged 20-24 (21-34\%; Table 1, pages 144-145); for another 13 , the greatest proportion was among women aged 25-29 (22-34\%); and for six, the greatest proportion was among women aged 30-34 (22-26\%). In Hong Kong and Latvia, equal proportions of abortions occurred in the 20-24 and 25-29 age-groups (21\% each and 23\% each, respectively); in Romania, an equal proportion of abortions occurred in the 20-24, 25-29 and 30-34 age-groups (22\% each). The proportion was generally lowest among women at either end of the reproductive spectrum (those younger than 20 and those 35 or older). For all 10 countries with information on abortions to females aged 15-17 and 18-19 in the most recent year, the greater proportion is accounted for by the 18-19 age-group, even though it consists of two years of youth and the 15-17 age-group consists of three.

Adolescents, defined here as 15-19-year-olds, accounted for a disproportionate share of abortions in relation to their share of the population in 11 countries. In Cuba and Scotland, adolescents made up 15\% of each country's population of females aged 15-44 (not shown), but accounted for $29 \%$ and $24 \%$ of all abortions, respectively. ${ }^{\dagger}$ Adolescents represent a disproportionate share of abortion in relation to their share of the population in nine other countries, but by margins smaller than five percentage points. In contrast, in 34 of the 45 countries with relevant information, adolescents accounted for a smaller share of all abortions than their share of the population would predict. In 20 of those countries, their share of abortions was at least five percentage points less than their share of the female population aged 15-44.

In 20 countries, fewer than $10 \%$ of abortions occurred among women younger than 20 (Figure 1, page 146). The proportion of abortions obtained by women in this agegroup was lowest in Albania, Azerbaijan, Cambodia, Georgia, Kazakhstan, Serbia and Ukraine ${ }^{\ddagger}(2-6 \%)$, and highest in Cuba, England and Wales, New Zealand and Scotland (20-29\%).

The proportion of abortions obtained by adolescent women did not change appreciably between 1996 and 2009 in most of the 30 countries with data for both time

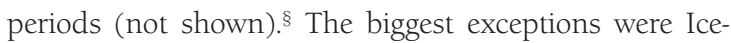
land-where this proportion fell by nearly half-and Kyrgyzstan and Romania-where the proportion more than doubled. The proportion rose by a smaller but still notable degree (11-36\%) in many northern European countries (including Denmark, Finland, Norway, Scotland and Sweden) as well as Croatia.

In many countries, the proportion of abortions obtained by adolescents rose between the mid-1990s and the early 2000s, and then declined. Although the differences over time were small in some cases, the pattern is nevertheless apparent in some northern European countries (most appreciably Estonia, Finland, Iceland and the Netherlands), as well as in Japan and Russia. In the eight countries for
TABLE 3. continued

\begin{tabular}{|c|c|c|c|c|c|c|c|c|}
\hline Country & Year & $15-19$ & $20-24$ & $25-29$ & $30-34$ & $35-39$ & $\geq 40$ & $\begin{array}{l}\text { Total abor- } \\
\text { tion rate* }\end{array}$ \\
\hline \multicolumn{9}{|c|}{ Incomplete statistics (cont.) } \\
\hline Lithuania & 2009 & 5.2 & 12.5 & 14.4 & 15.9 & 12.6 & 5.7 & 0.33 \\
\hline Mongolia & 2008 & 5.0 & 16.7 & 20.5 & 20.6 & 18.1 & 8.7 & 0.45 \\
\hline Puerto Rico & 2006 & 6.8 & 13.6 & 9.9 & 5.4 & 2.6 & 0.9 & 0.20 \\
\hline Romania & 2008 & 13.0 & 20.2 & 20.3 & 19.7 & 14.8 & 5.9 & 0.47 \\
\hline Russian Federation & 2009 & 16.7 & 53.0 & 57.0 & 50.3 & 35.4 & 15.1 & 1.14 \\
\hline Serbia & 2008 & 4.6 & 14.2 & 20.3 & 23.4 & 20.5 & 9.0 & 0.46 \\
\hline Singapore & 2010 & 8.3 & 23.8 & 21.9 & 15.6 & 11.2 & 4.0 & 0.42 \\
\hline Slovakia & 2009 & 6.1 & 11.5 & 13.5 & 14.5 & 12.0 & 5.6 & 0.32 \\
\hline \multicolumn{9}{|l|}{ Survey estimatesłキ } \\
\hline Albania§§ & 2009 & 1.0 & 3.0 & 11.0 & 7.0 & 5.0 & 2.0 & 0.15 \\
\hline \multicolumn{9}{|l|}{$\begin{array}{l}\text { Surveys/incomplete } \\
\text { statistics }\end{array}$} \\
\hline Armenia (statistics) & 2008 & 0.2 & 13.3 & 25.4 & 20.3 & 8.9 & 0.3 & 0.34 \\
\hline Armenia (survey)*† & 2010 & 3.0 & 33.0 & 59.0 & 44.0 & 19.0 & 8.0 & 0.83 \\
\hline Azerbaijan (statistics) & ‡ 2007 & 2.4 & 11.8 & 19.5 & 16.8 & 11.4 & $\mathrm{u}$ & 0.37 \\
\hline Azerbaijan (survey) ${ }^{*} \dagger$ & 2006 & 6.0 & 74.0 & 141.0 & 127.0 & 77.0 & 29.0 & 2.27 \\
\hline Ukraine (statistics) ${ }^{*} \neq$ & 2009 & 7.3 & 17.6 & $\mathrm{u}$ & $\mathrm{u}$ & 7.1 & $\mathrm{u}$ & 0.37 \\
\hline Ukraine (survey) & 2007 & 6.0 & 18.0 & 26.0 & 19.0 & 12.0 & 5.0 & 0.43 \\
\hline
\end{tabular}

*The number of abortions that an average woman will have in her lifetime at the prevailing period's agespecific abortion rates. †Based on incomplete official statistics. $¥$ Abortions among women $\geq 40$ are included in the 35-39 age-group. §Based on complete official statistics. ${ }^{* *}$ Age-groups: $\leq 19,20-34$ and $\geq 35$; does not include menstrual regulations. $†+A g e-g r o u p s: \leq 19,20-29,30-39$ and $\geq 40$. $\neq \neq$ Includes illegal abortions. $\S \S$ Based on all abortions in the three years preceding survey. ${ }^{*}+$ United Nations Population Division population estimates used to compute rates. ${ }^{*} \neq$ Age-groups: $\leq 19,20-34$ and $\geq 35$. Note: $u=$ unavailable.

which we have data only for 2003 and 2009, this proportion was virtually unchanged between the two periods.

At the regional level, adolescent females accounted for a larger proportion of all abortions in North America than in Europe (18\% vs. 11\%; Table 2 and Figure 2, page 147). Adolescents accounted for a larger proportion of abortions in the Northern European subregion (18\%) than in the other European subregions (8-13\%) or in Eastern Asia excluding China (9\%). Women aged 20-29 accounted for $57 \%$ of all abortions in North America and 47\% in Europe; this group accounted for $42-49 \%$ of abortions in the subregions represented by the data. The proportion of abortions obtained by females aged 30-39 was larger in Europe than in North America (35\% vs. 25\%); at the subregional level, this proportion was greatest in Eastern and Southern Europe (37\% and 40\%, respectively), and Eastern Asia excluding China (38\%). Data were available for only one country in Oceania: New Zealand. Using these data as a proxy for the region, however, we find that adolescent females accounted for a large share of all abortions (21\%Table 1), and women aged 30-39 accounted for a small share of all abortions (23\%), compared with the patterns in the other subregions presented here.

\section{*Abortions among females aged 15-34 in the most recent year are clas- sified in age-groups broader than five years in Cuba, Georgia, Kazakhstan and South Africa. For Ukraine, five-year age-groups are available from a survey. For Canada and Romania, abortions among women aged 35 or older are grouped together. In all countries, women aged 35 or older ac- count for a small proportion of all abortions.}

†Abortions among adolescents in Cuba are limited to females aged 15-18.

\#Based on official statistics.

$\S$ Trends are assessed on the basis of unrounded figures. 
FIGURE 3. Abortions per 1,000 females aged 15-19, by country

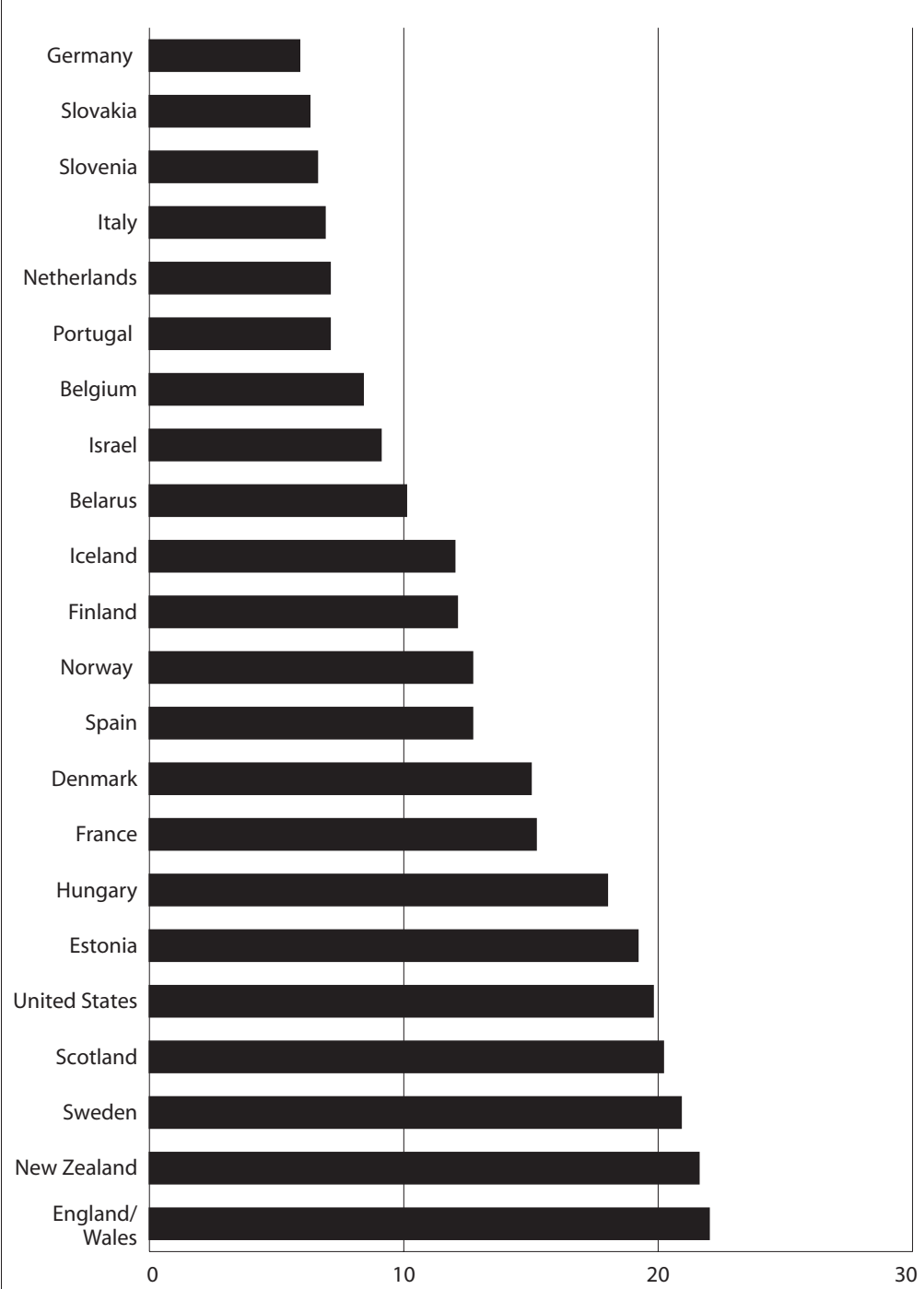

Note: Data are based on country data for the most recent year available; median year of all data was 2009.

\section{Abortion Rates}

Generally, country abortion rates show an inverted ushaped pattern by women's age (Table 3, page 148). In 23 of the 41 countries with relevant data, the highest agespecific abortion rate was among 20-24-year-olds, and in 10 countries, the highest rate was among 25-29-year-olds. The rate among women aged 30-34 was slightly higher than those among women aged 20-24 and 25-29 in seven countries (all former Soviet bloc countries, except Portugal). In just one country, Cuba, the highest age-specific abortion rate was among adolescents.

The highest recent adolescent abortion rates were observed in England and Wales, New Zealand, Sweden, Scotland and the United States (20-22 per 1,000 women; Figure 3). The lowest adolescent abortion rates among countries with complete reporting were in Germany, Slovakia, Slovenia, Italy, the Netherlands and Portugal (6-7).

*The rate also rose by $28 \%$ since 2003 in Spain, where a complete rate for the mid-1990s is not available.
The adolescent abortion rate increased by at least $10 \%$ in seven countries between the mid-1990s and the late 2000s, and decreased by at least that amount in eight countries (Table 3). Generally, the declines were sharper than the increases. The sharpest overall increases occurred in Belgium, the Netherlands and Scotland (22-42\%; not shown), ${ }^{*}$ and the steepest declines took place in Estonia, Hungary, Iceland, Slovakia and Slovenia (40-55\%). In Finland, the Netherlands, New Zealand and Sweden, the adolescent abortion rate rose between the mid-1990s and early 2000s, and then declined.

In many countries, low and high adolescent abortion rates reflect low and high overall levels of abortion. Exceptions include Cuba, Scotland, and England and Wales, where adolescent rates were higher than overall abortion rates, and Armenia, Azerbaijan and Georgia, where adolescent rates were quite low relative to overall rates. Similarly, trends in adolescent abortion rates often reflect trends in overall abortion rates; however, declines in the adolescent abortion rate in Iceland and Norway occurred despite relatively steady or increasing TARs.

\section{Total Abortion Rates}

The TAR was highest in Azerbaijan, where at current rates, the average woman would experience 2.3 abortions in her lifetime, even on the basis of survey data that likely underestimate abortion levels (Table 3). The Russian Federation and Cuba each had a high TAR as well (1.1 each). Although abortion rates have fallen dramatically in many countries of the former Soviet bloc in the past two decades, overall rates are still high in many of them. ${ }^{2}$ Among countries with complete reporting, the TAR was lowest in Belgium, Germany, Italy, the Netherlands and Portugal (0.2-0.3). The TAR fell by at least $10 \%$ in seven countries between the mid-1990s and the late 2000s, and it increased by at least $10 \%$ in six countries. The largest increases were in Belgium and the Netherlands, and the biggest declines were in Estonia, Italy, Slovakia and Slovenia.

\section{DISCUSSION}

This assessment provides the most recent estimates of the age patterns of abortion incidence in countries with liberal abortion laws, and the first known estimates of the average age distribution of legal abortions to women in subregions and regions where liberal or liberally interpreted laws prevail. We found that adolescents account for a larger proportion of all abortions in North America than in Europe, although adolescents' share of all abortions in Northern Europe is similar to their share in North America. In addition, adolescents account for a smaller share of abortions than their population size would predict in the majority of countries with liberal abortion laws and relevant data. Both age-specific abortion rates and the share of all abortions by age-group are generally highest in the mid-range of women's reproductive years.

This assessment was limited to the distribution of legal abortions, but nearly all abortions in North America 
and Europe are legal; ${ }^{1}$ thus the findings likely represent the overall patterns of abortion incidence in these regions. The majority of abortions are unsafe in the three major developing world regions-Africa, Asia and Latin America $^{1}$-and the estimated age distributions of unsafe abortions for those regions have been published elsewhere. ${ }^{10}$ Taken together, the findings suggest that the proportion of abortions among 15-19-year-olds is higher in Africa (22\%) than in any other major world region. * The proportion of abortions among women in their 20s is highest in North America (57\%), followed closely by Latin America (53\%). The share of abortions obtained by women in their 30s is highest in Europe (37\%).

The distribution of abortions by age likely reflects a combination of the distribution of the general population across age groups and the age patterns of unmet need for contraception. Unmet need is driven, in turn, by levels of sexual activity, childbearing aspirations, contraceptive use and fecundity. Although surveys and statistics on these factors in developed countries-which comprise the preponderance of countries with liberal laws-are limited, the implications of the findings with respect to these factors are discussed below.

A smaller proportion of adolescents than of women aged 20-34 are likely to be sexually active, and among the sexually initiated, adolescents are more likely than older women to have intercourse only sporadically. ${ }^{16,17}$ In the United States and likely elsewhere as well, both sexual initiation and activity are more prevalent among 18-19-yearolds than among 15-17-year-olds, ${ }^{17,18}$ and this probably contributes to the higher abortion rate in the former agegroup. Lower levels of sexual activity probably explain the relatively low incidence of abortion among adolescents in many countries. Research on abortion incidence limited to sexually active adolescents would help reveal whether this group has an exceptionally high risk of unintended pregnancy and abortion.

The prevalence of modern contraceptive use and the use of specific methods also vary across age-groups. ${ }^{19-21}$ Where documentation of the age patterns of contraceptive use is available, condom use is most prevalent among younger women, whereas the use of long-acting and permanent methods increases with age. Hormonal methods, such as the pill, tend to be more commonly used by women in their 20s than by teenagers or by older women. Many unintended pregnancies occur among women practicing contraception-as a result of method failure, inconsistent or improper use, or short gaps in use. ${ }^{22,23}$ The use of methods that are more prone to these outcomes, such as the condom and oral contraceptives, can explain some of the abortions obtained by women younger than 30 .

Nonuse of contraceptives leads to many-often the majority-of abortions, at least in the developing world. ${ }^{24}$ Compared with older women, young women seem to be more susceptible to pressure from peers to have sex without contraception, and more willing to engage in unprotected intercourse. ${ }^{25}$ Younger women also experience higher contraceptive failure and discontinuation rates than adult women. ${ }^{26}$ In addition, qualitative research suggests that young women have a more difficult time negotiating the use of user-dependent methods, particularly in unplanned sexual encounters, and that some are poorly informed about their risk of pregnancy. ${ }^{22,27}$ So, even if adolescents are less sexually active than women in the middle of their reproductive years, barriers to contraceptive use can increase sexually active adolescents' risk of pregnancy.

However, barriers to contraceptive use are experienced by women of all age-groups and regions. Common reasons given by women who want to avoid pregnancy for their nonuse of contraceptives include misperceptions about pregnancy risk, concern about side effects, unplanned intercourse and difficulty negotiating the use of maledependent methods. ${ }^{23,28,29}$

Prevailing childbearing aspirations evolve with age. Abortions among young women often reflect the desire to delay the start of childbearing, whereas among older women, they more likely reflect the desire to space or stop childbearing. The relatively high and rising abortion rates among 20-29-year-old women in many Northern and Western European countries (including Belgium, Denmark, England and Wales, Iceland, the Netherlands, Scotland and Sweden) likely in part mirror growing tendencies to postpone marriage and childbearing. The high abortion rates among women aged 30 or older (and large shares of abortions to women in this age-group) in many parts of Southern and Eastern Europe coincide with family formation patterns in which women desire small families, want to complete childbearing in their 20 s, and in some countries, tend not to use highly effective contraceptive methods. ${ }^{28}$ Female fecundity declines with age after the early 20s, ${ }^{30,31}$ which surely contributes in some degree to the lower abortion rates among older women in most countries.

The higher adolescent abortion rate in North America than in Europe is most likely primarily due to differences in contraceptive use: European teenagers have levels of sexual activity similar to those of their U.S. peers, but are more likely to use contraceptives and to favor the most effective methods. ${ }^{32,33}$ Contraception also appears to explain the decline in adolescent abortion rates in the United States in recent decades; this decline coincided with an increase in contraceptive use among adolescents, while the proportion of females aged 15-19 who were sexually experienced or engaging in sexual activity changed very little over those years ${ }^{5}$ (although some decline in sexual activity was observed among 15-17-year-olds ${ }^{18}$ ).

Abortion rates often mirror rates of unintended pregnancy. ${ }^{34}$ Although abortion rates are not exceptionally high among adolescents in most countries reviewed here, the high opportunity costs associated with unintended pregnancies that lead to unplanned births among adoles-

*Oceania is the only world region for which the average age distribution of abortions is not available. 
cents-and the fact that the adolescents of today are the adults of tomorrow-signal a need for improved access to sex education for young adults, as well as all sexually active adults. Education programs should include information about pregnancy risk, method choices and proper method use; counseling about negotiating contraceptive use in sexual relationships; and access to a range of methods. The incidence of unintended pregnancy among contraceptive users could also be reduced with more effective counseling about proper and consistent use, development and provision of more effective and easier-to-use methods, and the availability of a range of methods, so that women could alternate between methods or use dual methods, if desired. Still, some unintended pregnancies will inevitably occur for a range of reasons, including contraceptive failure.

The findings presented here demonstrate that, just as induced abortions occur in all societies, they also occur across the span of women's reproductive years. Thus, although our results show that women in certain age-groups are more likely than others to have abortions, and are probably in greater need of contraceptive information, contraceptive services and safe abortion care, they demonstrate the universality of abortion and of the need for such services. Nevertheless, investments in programs that help meet women's and couples' needs for contraceptive information and services would help lower the incidence of both unintended pregnancy and abortion. ${ }^{35}$

\section{REFERENCES}

1. Sedgh $G$ et al., Induced abortion: incidence and trends worldwide from 1995 to 2008, Lancet, 2012, 379(9816):625-632.

2. Sedgh $G$ et al., Legal abortion worldwide in 2008: levels and recent trends, International Perspectives on Sexual and Reproductive Health, 2011, 37(2):84-94.

3. Bankole A, Singh S and Haas T, Characteristics of women who obtain induced abortion: a worldwide review, International Family Planning Perspectives, 1999, 25(2):68-77.

4. Fielding JE and Williams CA, Adolescent pregnancy in the United States: a review and recommendations for clinicians and research needs, American Journal of Preventive Medicine, 1991, 7(1):47-52.

5. Santelli JS and Melnikas AJ, Teen fertility in transition: recent and historic trends in the United States, Annual Review of Public Health, 2010, 31(1):371-383.

6. Khan $\mathrm{S}$ and Vinod M, Youth reproductive and sexual health, DHS Comparative Reports, Calverton, MD, USA: Macro International, 2008, No. 19.

7. U.S. Bureau of the Census, Estimated Median Age at First Marriage, by Sex: 1890 to the Present, Current Population Survey, 2011, Table MS-2, <www.census.gov/population/socdemo/hh-fam/ms2.xls>, accessed June 12, 2012

8. Westoff $C$, Trends in marriage and early childbearing in developing countries, DHS Comparative Reports, Calverton, MD, USA: ORC Macro, 2003, No. 5.

9. Sedgh $G$ et al., Legal abortion worldwide: incidence and recent trends, International Family Planning Perspectives, 2007, 33(3): $106-116$.

10. Shah IH and Åhman E, Unsafe abortion differentials in 2008 by age and developing country region: high burden among young women, Reproductive Health Matters, 2012, 20(39):169-173.

11. Singh S et al., Abortion Worldwide: A Decade of Uneven Progress, New York: Guttmacher Institute, 2009.
12. United Nations, (UN), Demographic Yearbook 2008, New York: UN, 2010, Table 14, <http://unstats.un.org/unsd/demographic/ products/dyb/dyb2008/Table14.pdf>, accessed Feb. 8, 2011

13. Rossier C, Estimating induced abortion rates: a review, Studies in Family Planning, 2003, 34(2):87-102.

14. UN, Demographic Yearbook 2009-2010, New York: UN, 2011 Table 7, <http://unstats.un.org/unsd/demographic/products/dyb/ dybsets/2009-2010.pdf>, accessed Feb. 8, 2011.

15. Henshaw SK et al., eds., Readings on Induced Abortion, Volume 2: A World Review 2000, New York: Alan Guttmacher Institute, 2001, pp. 112-138.

16. Singh $S$ et al., Gender differences in the timing of first intercourse: Data from 14 countries, International Family Planning Perspectives, 2000, 26(1):21-28

17. Chandra A et al., Sexual behavior, sexual attraction, and sexual identity in the United States: data from the 2006-2008 National Survey of Family Growth, National Health Statistics Reports, 2011, No. 36, <http://www.cdc.gov/nchs/data/nhsr/nhsr036.pdf>, accessed Aug. 1, 2012.

18. Abma JC et al., Teenagers in the United States: sexual activity, contraceptive use, and childbearing, 2002, Vital and Health Statistics, 2004, 24(24):1-48.

19. Trussell J and Wynn LL, Reducing unintended pregnancy in the United States, Contraception, 2008, 77(1):1-5.

20. National Health Service (NHS) Information Centre, NHS Contraceptive Services: England, 2010/11 Community Contraceptive Clinics, London: Health and Social Care Information Centre, 2011.

21. Oddens BJ, Vemer HM and Everaerd WThAM, Towards a better understanding of contraceptive practice in Western countries: characterization of contraception users, in: Oddens BJ, ed., Determinants of Contraceptive Use: National Population-Based Studies in Various West European Countries, Delft, Netherlands: Eburon Publishers, 1996, pp. $17-47$.

22. Bajos $\mathrm{N}$ et al., Contraception: from accessibility to efficiency, Human Reproduction, 2003, 18(5):994-999.

23. Frost JJ, Singh S and Finer LB, U.S. women's one-year contraceptive use patterns, 2004, Perspectives on Sexual and Reproductive Health, 2007, 39(1):48-55.

24. Singh $S$ et al., Adding It Up: The Costs and Benefits of Investing in Family Planning and Maternal and Newborn Health, New York: Guttmacher Institute, 2009.

25. Gage AJ, Sexual activity and contraceptive use: the components of the decisionmaking process, Studies in Family Planning, 1998, 29(2):154-166

26. Blanc AK and Way AA, Sexual behavior and contraceptive knowledge and use among adolescents in developing countries, Studies in Family Planning, 1998, 29(2):106-116.

27. Hoggart L and Phillips J, Teenage pregnancies that end in abortion: what can they tell us about contraceptive risk-taking? Journal of Family Planning and Reproductive Health Care, 2011, 37(2):97-102.

28. Centers for Disease Control and Prevention (CDC) and ORC Macro, Reproductive, Maternal and Child Health in Eastern Europe and Eurasia: A Comparative Report, Atlanta, GA, USA: CDC; and Calverton, MD, USA: ORC Macro, 2003

29. Sedgh G et al., Women with an unmet need for contraception in developing countries and their reasons for not using a method Occasional Report, New York: Guttmacher Institute, 2007, No. 37

30. Gindoff PR and Jewelewicz R, Reproductive potential in the older woman, Fertility and Sterility, 1986, 46(6):989-1001.

31. Speroff L, The effect of aging on fertility, Current Opinion in Obstetrics \& Gynecology, 1994, 6(2):115-120

32. Santelli J, Sandfort T and Orr M, Transnational comparisons of adolescent contraceptive use: what can we learn from these comparisons? Archives of Pediatrics \& Adolescent Medicine, 2008, 162(1): 92-94. 
33. Darroch JE, Singh S and Frost JJ, Differences in teenage pregnancy rates among five developed countries: the roles of sexual activity and contraceptive use, Family Planning Perspectives, 2001, 33(6):244$250 \& 281$.

34. Singh S, Sedgh G and Hussain R, Unintended pregnancy: worldwide levels, trends, and outcomes, Studies in Family Planning, 2010, 41(4):241-250.

35. Shellenberg KM et al., Social stigma and disclosure about induced abortion: results from an exploratory study, Global Public Health, 2011, 6(Suppl. 1):S111-S125.

\section{RESUMEN}

Contexto: La evaluación de los niveles y tendencias del aborto por edad de las mujeres en el momento del procedimiento puede usarse para monitorear las tendencias del embarazo no planeado por edad. Dicha evaluación también puede dar soporte a los programas y políticas relevantes.

Métodos: Se compilaron datos sobre la incidencia del aborto legal de oficinas nacionales de estadísticas y a partir de encuestas representativas a nivel nacional de más de 40 países en donde el aborto legal está generalmente disponible. Se calcularon las tasas de aborto por grupo de edad específica y la distribución porcentual de los abortos por edad; y se examinaron las tendencias desde 1996 y 2003 hasta 2009. Se desarrollaron estimaciones subregionales y regionales para las áreas geográficas en donde la mayor parte de la población estuvo representada por los datos.

Resultados: El año mediano para las estimaciones más recientes de abortos por edad fue de 2009. En la mayoría de los países elegibles con datos, las adolescentes representaron una proporción más pequeña de los abortos que su proporción en la población. En general, la proporción del total de abortos que correspondia a las mujeres adolescentes fue más alta en América del Norte (18\%) que en Europa en su conjunto (11\%), aunque la proporción en Europa del Norte fue la misma que la en América del Norte (18\%). Además, la tasa de aborto específica por edad más alta y la contribución más alta al total de los procedimientos se observaron en mujeres en edades de 20-29. A partir de 1996, las tasas de aborto en adolescentes han aumentado principalmente en Bélgica, Escocia y los Países Bajos (en 22-42\%); y han disminuido principalmente en Estonia, Eslovaquia, Eslovenia, Hungría e Islandia (en 40-55\%).

Conclusiones: Las tasas de aborto más altas en ciertos grupos de edad probablemente reflejan niveles más altos que el promedio de necesidad insatisfecha de anticoncepción o difcultad para usar métodos de manera consistente y efectiva, así como un fuerte deseo de evitar la maternidad. Cada uno de los patrones observados tiene implicaciones para las necesidades de servicios e información dentro de los países.

\section{RÉSUMÉ}

Contexte: Les évaluations des niveaux et tendances de l'avortement en fonction de l'âge des femmes au moment de la procédure peuvent servir à surveiller celles des grossesses non planifiées suivant l'âge et apporter une information utile aux programmes et politiques concernés.

Méthodes: Des données concernant l'incidence de l'avortement légal ont été compilées auprès des offices nationaux de la statistique et d'après les enquêtes nationalement représentatives de plus de 40 pays où la procédure est généralement accessible. Les taux d'avortement en fonction de l'âge et la répartition des IVG suivant l'âge ont été calculés, avec examen des tendances depuis 1996 et 2003. Des estimations sousrégionales et régionales ont été établies pour les zones géographiques où la majorité de la population était représentée par les données.

Résultats: L'année médiane des estimations les plus récentes de l'avortement en fonction de l'âge de la femme est 2009. Les adolescentes représentent une part moindre des avortements pratiqués que leur part de la population dans la majorité des pays admis dotés de données. Dans la plupart des pays, les taux et les proportions d'IVG les plus élevés en fonction de l'âge concernent les femmes de 20 à 29 ans. Depuis 1996, les taux d'avortement parmi les adolescentes ont augmenté le plus en Belgique, aux Pays-Bas et en Écosse (22-42\%), tandis qu'ils diminuaient le plus en Estonie, en Hongrie, en Islande, en Slovaquie et en Slovénie (40-55\%). La proportion des avortements obtenus par les adolescentes est plus élevée en Amérique du Nord (18\%) qu'en Europe dans l'ensemble (11\%), bien que la proportion atteinte dans le nord européen (18\%) soit identique à celle relevée en Amérique du Nord.

Conclusions: Les taux d'avortement supérieurs dans certains groupes d'âge reflètent probablement des niveaux de besoin de contraception non satisfait ou une difficulté de pratique contraceptive constante et efficace supérieurs à la moyenne, ainsi qu'un plus grand désir d'éviter la maternité. Chacune des tendances observées présente des implications concernant les besoins de services et d'information au sein des pays.

\section{Acknowledgments}

The authors thank Evert Ketting for his role in data collection and assessments of data quality, and Alyssa Tartaglione for her help with data collection and data management.

Author contact:gsedgh@guttmacher.org 